\title{
Peran Etika Egoisme Sebagai Pemoderasi Pengaruh Keefektifan Pengendalian Internal dan Profesionalisme Auditor Internal Terhadap Pengungkapan Fraud
}

\author{
Riyas Tuti ${ }^{1}$, Susi Dwi Mulyani ${ }^{2 *}$ \\ 1,2Universitas Trisakti Jakarta, Indonesia \\ 1riyastuti200@gmail.com, 2susi.dwimulyani@trisakti.ac.id \\ *Penulis Korespondensi
}

\begin{abstract}
Fraud disclosure is needed for companies to avoid actions that can harm the company. This study aims to analyze the effect of internal control effectiveness and internal auditor professionalism on fraud disclosure by using a moderating variable, namely ethics-egoism. The data had been obtained from the perceptions of accounting students from the Faculty of Economics and Business, Trisakti University. The sample had been obtained by purposive sampling method is 114 respondents. The results show that the internal control effectiveness has a positive effect on fraud disclosure, while the internal auditor professionalism has no effect on fraud. The results of this study also prove that ethics of selfishness as a moderating variable is able to weaken the effect of the internal control effectiveness on fraud disclosure, but is not able to weaken the effect of internal auditor professionalism auditors on fraud disclosure.
\end{abstract}

Keywords: fraud disclosure, internal control effectiveness, internal auditor professionalism, ethics of selfishness

\begin{abstract}
Abstrak
Pengungkapan fraud diperlukan untuk perusahaan supaya tidak terjadi tindakan-tindakan yang dapat merugikan perusahaan. Hal ini dipengaruhi oleh sistem pengendalian internal yang ada di perusahaan yang kurang efektif dan Auditor internal yang dirasa kurang profesional. Penelitian ini bertujuan untuk menganalisis pengaruh keefektifan pengendalian internal dan profesionalisme auditor internal terhadap pengungkapan fraud dengan menggunakan variabel moderasi yaitu etika egoisme. Data diperoleh dari persepsi mahasiswa akuntansi Fakultas Ekonomi dan Bisnis Universitas Trisakti. Sampel yang didapatkan berdasarkan metode purposive sampling yaitu 114 responden. Hasil penelitian menunjukkan bahwa keefektifan pengendalian internal berpengaruh positif terhadap pengungkapan fraud, sedangkan profesionalisme auditor internal tidak berpengaruh terhadap pengungkapan fraud. Hasil penelitian ini pun membuktikan bahwa etika egoisme sebagai variabel moderasi ini mampu memperlemah pengaruh keefektifan pengendalian internal terhadap pengungkapan fraud, tetapi tidak mampu memperlemah pengaruh profesionalisme auditor internal terhadap pengungkapan fraud.
\end{abstract}

Kata kunci: keefektifan pengendalian internal, profesionalisme auditor internal, pengungkapan fraud, etika egoisme

\section{Cara Mengutip:}

Tuti, R. \& Mulyani, D. M (2021) Peran Etika Egoisme Sebagai Pemoderasi Pengaruh Keefektifan Pengendalian Internal dan Profesionalisme Auditor Internal Terhadap Pengungkapan Fraud. Esensi: Jurnal Bisnis dan Manajemen, Vol 11(2), 169-176. https://doi.org/10.15408/ess.v11i2.22644. 


\section{PENDAHULUAN}

Fraud merupakan tindakan yang disengaja oleh beberapa pihak dimana aktivitas untuk menghilangkan suatu harta benda yang dilakukan dengan cara memanipulasi, korupsi atau pencurian yang dilakukan oleh pihak yang tidak bertanggung jawab demi keuntungan pribadi (Zimbelman dkk., 2014). Fraud dapat disebabkan karena pengendalian internalnya yang tidak efektif. Sistem pengendalian internal yang tidak efektif dapat mempercepat terjadinya tindak kecurangan. Sistem pengendalian internal sendiri merupakan suatu proses yang dirancang di perusahaan dan perlu dijalankan oleh setiap individu di dalam perusahaan untuk mencapai tujuan perusahaan. Unsur sistem pengendalian internal antara lain terdapat didalamnya sumber daya manusia dan sistem teknologi informasi yang berguna membantu perusahaan dalam mencapai tujuannya.

Pengendalian internal juga merupakan suatu cara untuk mengorganisir, mengawasi serta mengukur apakah sumber daya dalam suatu organisasi berjalan dengan baik, maka pengendalian internal berperan penting dalam mengungkapkan terjadinya fraud dengan cepat karena jika suatu perusahaan yang pengendalian internalnya tidak dirancang dengan baik maka semakin cepat perusahaan mengalami fraud, begitu sebaliknya apabila perusahan memiliki sistem pengendalian yang terstruktur dengan baik perusahaan dapat meminimalisir terjadinya fraud.

Maliawan dkk. (2017) telah membuktikan bahwa efektivitas pengendalian internal berpengaruh terhadap pencegahan fraud. Hal ini berarti sistem pengendalian internal yang terdapat dalam perusahaan sangat mempengaruhi tingkat fraud, semakin efektif sistem pengendalian yang diterapkan dalam suatu entitas, maka semakin rendah kecenderungan fraud yang mungkin terjadi. Pada penelitian yang dilakukan Nuraeni (2016) menghasilkan bahwa efektifivitas pengendalian internal berpengaruh positif terhadap Fraud pada Bank Syariah Mandiri Cabang Ahmad Yani Bandung. Nuraeni (2016) menyebutkan bahwa pengendalian internal memegang peranan penting untuk meminimalisir Fraud yang mungkin akan terjadi.

Tindakan melakukan kecurangan juga didasari dari keinginan seseorang yang motivasinya untuk menguntungkan pribadi atau organisasi. Selain pengendalian internal yang kurang efektif, tidak profesionalnya seorang auditor internal juga menjadi salah satu seseorang melakukan tindak kecurangan. Seorang auditor internal dituntut untuk menjalankan tugasnya secara profesional. Setiap auditor internal bertindak sungguh-sungguh dan sesuai dengan standar professional dan standar teknis yang berlaku, serta mencapai dan mempertahankan pengetahuan serta keahlian profesional pada level yang disyaratkan untuk memastikan bahwa organisasi tempatnya bekerja memperoleh jasa profesional yang kompeten berdasarkan standar-standar teknis terkini dan sesuai dengan perundang-undangan yang berlaku.

Nurmin (2017) menjelaskan bahwa seseorang dianggap memiliki profesionalisme melalui 5 (lima) dimensi, yaitu: i) pengabdian pada profesi, ii) kewajiban sosial, iii) kemandirian, iv) keyakinan terhadap profesi, dan v) hubungan dengan rekan seprofesi. Seseorang dapat dikatakan profesional apabila memiliki 3 (tiga) kriteria dalam setiap menjalankan tugasnya, yaitu: i) memiliki keahlian dalam menjalankan pekerjaannya sesuai dengan bidangnya dalam perusahaan tempat ia bekerja; ii) dapat melaksanakan tugas yang diemban dengan standarstandar yang berlaku di perusahaan tempatnya bekerja; iii) menjalankan tugas atau bekerja sesuai dengan etika profesi dan memiliki moralitas yang tinggi.

Pertiwi (2010) telah meneliti pengaruh komponen keahlian internal auditor terhadap pendeteksian dan pencegahan kecurangan (fraud) di Inspektorat Jenderal Kementerian 
Perdagangan Republik Indonesia. Hasil penelitian menunjukkan bahwa komponen keahlian internal auditor berpengaruh positif terhadap pendeteksian dan pencegahan fraud. Hal ini didukung oleh Widaningsih \& Hakim (2015) bahwa profesionalisme auditor internal berpengaruh positif terhadap pencegahan kecurangan dan pendeteksian kecurangan.

Etika juga merupakan salah satu komponen penting yang harus dimiliki seorang auditor internal, karena etika mengukur sejauh mana seorang dianggap mampu bekerja dengan baik di dalam suatu perusahaan. Salah satu kasus etika yang mungkin dan sering terjadi yaitu masalah mengenai kecurangan. Iklim etika juga berpengaruh kepada auditor internal untuk melakukan kecurangan. Iklim etika memiliki tiga jenis yaitu iklim etika egoisme, kebajikan, dan prinsip. Dalam pengambilan keputusan seorang auditor internal apabila didasarkan pada iklim etika egoisme maka keputusan tersebut cenderung mengedepankan kepentingan individu. Dengan adanya sikap profesionalisme dan independensi yang tinggi oleh seorang auditor internal tetapi iklim etika egoisme yang juga tinggi, maka akan berpengaruh pada rendahnya kemungkinan untuk mencegah terjadinya tindakan fraud Wijaya \& Adechandra (2020).

Kasus fraud yang baru-baru ini terjadi yaitu korupsi yang dilakukan oleh seorang manajer dan staf keuangan di kantor pos Medan. Kasus ini terjadi karena sang manajer keuangan Maraud Nainggolan (50) sebagai tersangka terjadi karena dia sebagai seorang manajer keuangan dan benda pos materai (BPM) tidak menjalankan pekerjaannya sesuai dengan yang seharusnya. Ia seharusnya melaksanakan pengawasan dan pemeriksaan yang merupakan tugasnya sebagai manajer tetapi malah lalai dalam tugasnya dan bekerja sama dengan staf keuangannya melakukan aksi korupsi yang dampaknya merugikan perusahaan hingga dua miliar (Hutauruk, 2020).

Penelitian sebelumnya yang dilakukan oleh Nur \& Hamid (2018) dalam mengungkapkan hal hal yang menyimpang atau usaha untuk mengungkapkan fraud yang muncul di perusahaan, whistleblowing merupakan kegiatan yang tepat. Nur \& Hamid (2018) membuktikan bahwa tingkat profesionalisme yang tinggi serta moralitas auditor berpengaruh terhadap pengungkapan fraud dengan kegiatan whistleblowing. Berbeda dengan penelitian yang dilakukan oleh Cahyani \& Wahyundari (2020) hasil penelitiannya membuktikan bahwa pengendalian internal yang efektif berpengaruh terhadap pengungkapan fraud dengan kegiatan whistleblowing. Cahyani \& Wahyundari (2020) menyebutkan semakin efektif pengendalian internalnya maka semakin mudah mengungkapkan fraud dengan kegiatan whistleblowing.

Teori keagenan merupakan teori yang dibangun berdasarkan pada hubungan antara agen dan principal (Jensen \& Meckling, 1976). Teori ini mengacu pada manajer perusahaan (agen) diberi wewenang untuk mengelola perusahaan oleh pemilik (principal). Manajer sebagai agen perlu menyampaikan informasi atau sinyal tentang kondisi bisnis kepada pemilik. Namun, informasi yang dikirimkan seringkali tidak sesuai dengan keadaan yang sebenarnya, karena ada kecenderungan agen memuaskan keinginan pribadi. Oleh karena itu, diperlukan adanya pengendalian internal yang baik sebab manajemen harus melakukan pengelolaan perusahaan dan mempertanggungjawabkan kinerjanya melalui laporan keuangan, sehingga manajer dapat menyajikan laporan keuangan secara wajar. Disamping itu diperlukan peran auditor internal yang profesional untuk memonitor dan mengevaluasi kinerja manajer perusahaan. Dalam hal ini manajer perusahaan (agen) dan auditor internal yang ada di dalam perusahaan perlu mengesampingkan sikap egosime yang dimiliki untuk membantu meminimalisir terjadinya fraud di dalam perusahaan.

Orisinalitas penelitian ini, antara lain: (1) penggabungan penelitian Wijaya \& 
Adechandra (2020) dan Setyawati et al. (2015). Wijaya \& Adechandra (2020) menggunakan salah satu variabel independennya yaitu profesionalisme auditor internal dengan etika egoisme sebagai variable moderasinya. Kemudian penelitian ini menambahkan satu variabel independen yaitu keefektifan pengendalian internal dari Setyawati et al. (2015) karena penelitian ini ingin mengetahui sejauh mana pengendalian internal yang efektif dapat mengungkapan tindakan fraud. Kedua, responden dalam penelitian ini berbeda dengan responden yang digunakan Wijaya \& Adechandra (2020) dan Setyawati et al. (2015). Penelitian ini menggunakan responden mahasiswa jurusan akuntansi yang telah menempuh mata kuliah auditing, karena mahasiswa akuntansi merupakan calon orang-orang yang nantinya memiliki kemungkinan bekerja pada bidang akuntansi, auditor internal, dan auditor eksternal yang harus memiliki keberanian untuk mengungkap suatu tindak fraud yang dilakukan di suatu perusahaan.

\section{METODE}

Penelitian ini merupakan studi kausalitas yang bertujuan untuk menguji pengaruh keefektifan pengendalian internal dan profesionalisme auditor internal terhadap pengungkapan fraud dengan etika egoisme sebagai variabel moderasi. Populasi yang digunakan dalam penelitian ini adalah mahasiswa akuntansi kelas karyawan Universitas Trisakti. Responden penelitian ini adalah mahasiswa akuntansi yang telah menempuh mata kuliah Sistem Informasi Akuntansi, Etika Profesi, serta Audit Internal. Diharapkan setelah lulus dan bekerja, mahasiswa tersebut memiliki keberanian mengungkap suatu tindak kecurangan yang dilakukan suatu organisasi.

Studi ini menggunakan data primer dengan unit analisis penelitian adalah persepsi individu responden yang pengumpulan datanya menggunakan kuesioner dengan pengukuran skala likert. Indikator pengukuran masing-masing variabel penelitian sebagai berikut:

A. $\quad$ Pengungkapan Fraud (Koroy, 2008):

1. Mengidentifikasi hambatan mengungkap Fraud

2. Bentuk bentuk Fraud dan pihak-pihak yang melakukan Fraud

3. Keefektifan metode dan prosedur audit, serta keterbukaan manajemen klien merupakan hal penting

4. Pengungkapan kepada publik.

5. Penyampaian tertulis manajemen klien, dan penerbitan opini selain unqualified opinion

B. Keefektifan pengendalian internal (Prihandoko, 2020):

1. Lingkungan Pengendalian

2. Penaksiran Resiko

3. Aktivitas Pengendalian

4. Inforamsi dan Komunikasi

5. Pemantauan dan Monitoring

C. Profesionalisme auditor internal (Tjandrawinata, 2013):

1. Tanggung jawab.

2. Integritas.

3. Objektifitas dan Kemandirian

4. Kehati-hatian

5. Ruang Lingkup dan Sifat Jasa. 
D. Etika egoisme (Floyd, 2010):

1. Mementingkan kepentingan pribadi.

2. Mementingkan kepentingan perusahaan

3. Pekerjaan dianggap tidak lancar dan meragukan

4. Keputusan mengenai benar atau salah hanya berdasarkan keputusan pribadi

Pengolahan data menggunakan alat bantu SPSS dengan melakukan serangkaian uji: validitas, reliabilitas, normalitas, dan multikolinearitas, sebelum melakukan uji hipotesis yaitu dengan melakukan uji kefisien determinasi $\left(\mathrm{R}^{2}\right)$, Uji serentak (Uji F), dan Uji parameter individu (Uji t). penelitian ini menggunakan tingkat signifikansi $\alpha=5 \%$. Persamaan regresi berganda dengan variabel moderasi sebagai berikut: FRAUD $=-\alpha+\beta_{1} \mathrm{X} 1+\beta_{2} \mathrm{X} 2+\beta_{3} \mathrm{Z}-\beta_{4} \mathrm{Z}^{*} \mathrm{X} 1+\beta_{5} \mathrm{Z}$ X2 $+\epsilon$

Alur pemikiran dan hubungan antar variabel dalam penelitian ini dapat dilihat pada Gambar 1.

Gambar 1. Kerangka Konseptual

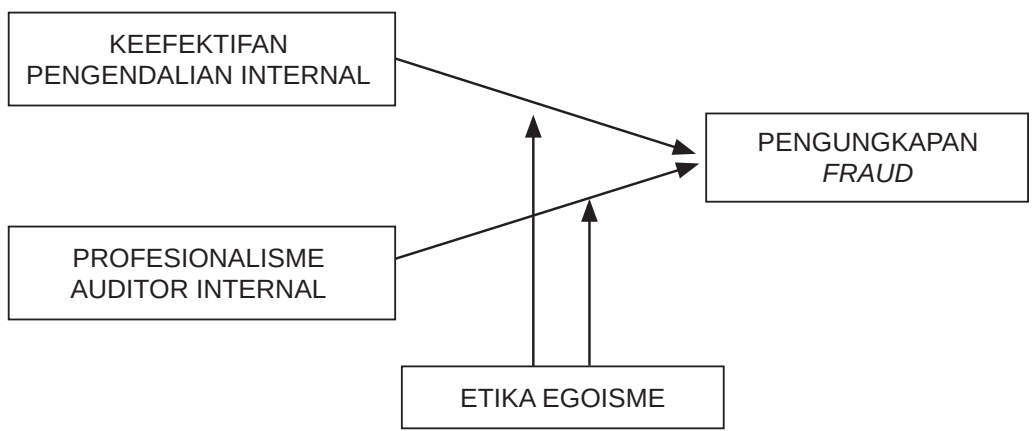

\section{HASIL DAN PEMBAHASAN}

Total kuesioner yang disebarkan kepada responden berjumlah 120 kuesioner, namun kuesioner yang kembali dan dinyatakan dapat diolah sebanyak 114 responden. Berikut demografi responden berdasarkan jenis kelamin. Hal ini dapat dilihat pada Tabel 1.

Tabel 1. Jenis Kelamin Responden

\begin{tabular}{ccc}
\hline Keterangan & Frekuensi & Persentase \\
\hline Laki-laki & 18 & 15.8 \\
Perempuan & 96 & 84.2 \\
\hline TOTAL & 114 & 100.0 \\
\hline
\end{tabular}

Sumber: data diolah (2021)

Jawaban responden menunjukkan nilai rata-rata paling rendah adalah variabel pengungkapan fraud $(3,79)$, sedangkan rata-rata variabel lainnya diatas 4 . Hal ini menunjukkan responden menjawab "setuju". Nilai deviasi standar juga menunjukkan angka yang jauh lebih kecil dibandingkan nilai rata-ratanya yang menunjukkan data bersifat homogen.

Hasil uji validitas menggunakan uji Pearson Correlation menunjukkan tingkat signifikansinya di bawah 0,05, maka seluruh butir pertanyaan tersebut dikatakan valid. Hasil uji reliabilitas menunjukkan nilai Croncbach Alpha berada diatas 0,60, sehingga kuesioner setiap variable 
dinyatakan reliabel (Hair dkk., 2014). Uji normalitas menggunakan One-Sample Kolmogorov Smirnov Test diperoleh nilai Asymp. Sig. (2-tailed) sebesar 0,077 lebih besar dari 5\% dan hasil uji multikolinearitas memberikan hasil nilai VIF $>10$. Hal ini menunjukkan terjadi permasalahan yang disebabkan oleh penggunaan variabel moderasi dalam persamaan regresinya. Oleh karena itu permasalahan ini dapat diabaikan dalam penelitian ini Gujarati \& Porter (2010). Hasil pengujian hipotesis menggunakan model regresi berganda dengan variable moderasi dapat dilihat pada Tabel 3.

Tabel 2. Statistik Deskriptif

\begin{tabular}{lccc}
\hline \multicolumn{1}{c}{ Variabel } & Jumlah sampel & Rata-rata & Deviasi standar \\
\hline Keefektifan pengendalian internal & 114 & 4.61 & 0.530 \\
Profesionalisme auditor internal & 114 & 4.47 & 0.562 \\
Pengungkapan fraud & 114 & 3.79 & 0.816 \\
Etika egoisme & 114 & 4.26 & 0.735 \\
\hline
\end{tabular}

Sumber: data diolah (2021)

Tabel 3. Uji statitik t

\begin{tabular}{|c|c|c|c|c|c|c|c|}
\hline Variabel & Prediksi arah & $\beta$ & Sig (one tail) & Keputusan & Adj $R^{2}$ & $\mathbf{F}$ & sig \\
\hline Keefektifan & + & 1.364 & 0.018 & $\mathrm{H}_{1}$ diterima & 0,507 & 24,260 & 0,000 \\
\hline Profesionalisme & + & 0.374 & 0.254 & $\mathrm{H}_{2}$ ditolak & & & \\
\hline Keefektifan*Egoisme & - & -0.080 & 0.040 & $\mathrm{H}_{3}$ diterima & & & \\
\hline Profesionalisme*Egoisme & - & 0.003 & 0.4725 & $\mathrm{H}_{4}$ ditolak & & & \\
\hline
\end{tabular}

Nilai Adjusted $R$ square sebesar 0,507 dapat diartikan bahwa variabel keefektifan pengendalian internal, profesionalisme auditor internal, dan etika egoisme sebagai variabel moderasi dapat menjelaskan variasi pengungkapan fraud sebesar 50,7\%, sisanya 49,3\% dijelaskan variabel di luar model penelitian ini. Hasil uji F, diketahui nilai F-hitung sebesar 24,260 dengan nilai signifikansi 0,000 < 0,05, sehingga model layak digunakan. Hasil uji hipotesis menggunakan uji t sebagai berikut:

Hipotesis pertama diterima, keefektifan pengendalian internal berpengaruh positif terhadap pengungkapan fraud. Hasil ini mendukung Lestari \& Yaya (2017)bahwa kecenderungan kecurangan akuntansi dipengaruhi oleh ada atau tidaknya peluang untuk melakukan hal tersebut. Peluang tersebut dapat diminimalisir dengan adanya pengendalian internal yang efektif. Sistem pengendalian internal memegang peran penting dalam organisasi. Dengan adanya sistem pengendalian yang efektif, maka kegiatan operasional juga dapat berjalan secara efektif. Dengan demikian, semakin efektif sistem pengendalian yang diterapkan dalam suatu entitas, maka semakin rendah kecenderungan kecurangan akuntansi yang mungkin terjadi.

Hasil pengujian hipotesis kedua ditolak. Berdasarkan tabel 3 dapat dilihat variabel profesionalisme auditor internal internal tidak berpengaruh terhadap pengungkapan fraud dengan nilai sig 0,254 >0,05. Hasil ini sejalan dengan Cahyani \& Wahyundari (2020) bahwa profesionalisme auditor internal tidak berpengaruh terhadap pengungkapan kecurangan akuntansi dengan Whistleblowing. Walaupun semakin baik profesionalisme auditor internal tidak akan meningkatkan pengungkapan kecurangan akuntansi dengan Whistleblowing. Hal ini menunjukkan bahwa sekalipun auditor internalnya professional, tetap diperlukan sistem pengendalian internal yang efektif untuk mengungkap fraud. 
Berdasarkan tabel 3, hipotesis ketiga diterima yang berarti etika egoisme dapat memperlemah pengaruh positif keefektifan pengendalian internal terhadap pengungkapan fraud. Hal ini membuktikan walaupun sistem pengendalian internal perusahaannya bagus tetapi masih terdapat sikap egois dari seorang manajer perusahaan maka dapat menurunkan mengungkapkan fraud yang terjadi. Hal ini menjadi penting untuk mengurangi sikap egoisme yang ada dalam diri manajer. Hasil ini konsisten dengan Ahmad (2011) yang menyatakan bahwa etika egoisme menurunkan niat untuk melakukan Whistleblowing internal.

Hasil pengujian hipotesis keempat ditolak, yang berarti etika egoisme tidak dapat memperlemah pengaruh positif profesionalisme auditor internal terhadap pengungkapan fraud. Hasil ini konsisten dengan hasil uji pengaruh langsung profesionalisme auditor internal terhadap pengungkapan fraud. Hasil ini mendukung Distianto (2019) dan Ramdhani (2018) dimana iklim etika yang baik maka tidak mengindikasikan terjadinya kecurangan dan kode etik mendorong seseorang untuk melakukan tindakan Whistleblowing yang merupakan salah satu cara untuk mencegah terjadinya kecurangan.

\section{SIMPULAN}

Berdasarkan analisis data, pengujian hipotesis, dan pembahasannya, penelitian ini membuktikan bahwa: keefektifan pengendalian internal berpengaruh positif terhadap pengungkapan fraud dan etika egoisme dapat memperlemah pengaruh positif keefektifan pengendalian internal terhadap pengungkapan fraud, sedangkan profesionalisme auditor internal internal tidak berpengaruh terhadap pengungkapan fraud dan etika egoisme tidak dapat memperlemah pengaruh positif profesionalisme auditor internal terhadap pengungkapan fraud. Keterbatasan penelitian ini antara lain: jawaban merupakan persepsi responden yang mempunyai tingkat subjektifitas tinggi dan terdapat gejala multikolinearitas yang diabaikan dalam penelitian ini.

Penelitian ini dapat memberikan masukan kepada manajemen entitas untuk memperhatikan keefektifan pengendalian internal, karena dapat meningkatkan pengungkapan fraud dan etika egoisme dari manajemen harus diturunkan agar tidak memperlemah peran keefektifan pengendalian internal dalam meningkatkan pengungkapan fraud. Penelitian selanjutnya disarankan menambah respondennya, menambah butir pernyataan kuesioner sehingga menjadi lebih detail dalam memperoleh persepsi responden, dan menambah variabel yang mampu mempengaruhi pengungkapan fraud, misalnya independensi auditor internal dan skeptisme auditor internal.

\section{PUSTAKA ACUAN}

Ahmad, S. A. (2011). Internal Auditors and Internal Whistleblowing Intensions: A Study of Organisasional, Individual, Situational and Demographic Factors. (Unpublished Thesis). Edith Cowan University, Western Australia.

Cahyani, D. K., \& Wahyundari, S. D. (2020). Pengaruh Profesionalisme Auditor, Efektivitas Pengendalian Internal Perusahaan Serta Keadilan Organisasi Terhadap Pengungkapan Kecurangan Akuntansi Dengan Whistlwblowing. Prosiding Konferensi Ilmiah Mahasiswa Unissulu (KIMU) 3, 628-644.

Distianto, B. O. (2019). Pengaruh Gaya Kepemimpinan melalui Pelembagaan Etika, Iklim Kerja Etis serta Sikap Karyawan terhadap Kecenderungan Kecurangan Akuntansi (Fraud). (Tesis Tidak Dipublikasikan). Universitas Katolik Soegijapranata.

Floyd, K. S. (2010). Leadership Styles, Ethics Institutionalization, Ethical Work, Climate, and Employee 
Attitudes toward Information Technology Misuse in Higher Education: A Correlational Study. (Unpublished Thesis). College of Graduate Studies, Georgia Southern University.

Gujarati, D. N., \& Porter, D. C. (2010). Dasar-dasar Ekonometrika (5th ed). Jakarta: Salemba Empat. Hair, J. F., Sarstedt, M., Hopkins, L., \& Kuppelwieser, V. G. (2014). Partial Least Squares Structural Equation Modeling (PLS-SEM): an Emerging Tool in Business Research. European Business Review, 26(2), 106-121.

Jensen, M. C., \& Meckling, W. H. (1976). Theory of the Firm: Managerial Behavior, Agency Costs and Ownership Structure. Journal of Finance Economics, 3(4), 305-360.

Koroy, T. R. (2008). Pendeteksian Kecurangan (Fraud) Laporan Keuangan oleh Auditor Eksternal. Jurnal Akuntansi Dan Keuangan, 10(1), 22-33.

Lestari, R., \& Yaya, R. (2017). Whistleblowing dan Faktor-Faktor yang Mempengaruhi Niat Melaksanakannya oleh Aparatur Sipil Negara. Jurnal Akuntansi, XXI(3), 336-350.

Maliawan, ida bagus D., Sujana, E., \& Diatmika, I. P. G. (2017). Pengaruh Audit Internal Dan Efektivitas Pengendalian Interen Terhadap Pencegahan Kecurangan( FRAUD ) ( Studi Empiris pada Bank Mandiri Kantor Cabang Area Denpasar). Akuntansi, 8(2), 1-12.

Nur, S. W., \& Hamid, N. A. (2018). Pengaruh Profesionalisme dan Intensitas Moral Auditor Terhadap Intensi Melakukan Whistleblowing Pada Kantor Akuntan Publik Makassar. Jurnal Assets: Jurnal Ekonomi, Manajemen, Dan Akuntansi, 8(2), 115-124.

Nuraeni. (2016). Pengaruh Efektivitas Sistem Pengendalian Internal dan Kualitas Sumber Daya Manusia terhadap Faud pada Bank Syariah Mandiri Cabang Ahmad Yani Bandung. Jurnal Ekspansi, 8(2), 237-260.

Nurmin. (2017). Pengaruh Profesionalisme Auditor Internal Terhadap Pengungkapan Kecurangan. Jurnal Akuntansi (JAk), 2(1), 14-26.

Pertiwi, E. P. (2010). Analisis Pengaruh Komponen Keahlian Internal Auditor terhadap Pendeteksian dan Pencegahan (Fraud) di Inspektorat Jenderal Kementerian Perdagangan Republik Indonesia. (Skripsi Tidak Dipublikasikan). UIN Syarif Hidayatullah Jakarta.

Prihandoko, W. (2020). Pengaruh Keefektifan Pengendalian Internal, Ketaatan Aturan Akuntansi, dan Kepuasan Kerja Terhadap Kecurangan Akuntansi. Konferensi Ilmiah Mahasiswa UNISSULA (KIMU), 434-499.

Ramdhani, R. (2018). Pengaruh Audit Internal dan Whistleblowing System terhadap Pencegahan Kecurangan (Fraud) (Studi Kasus Pada PT PLN Persero Distribusi Jawa Barat). (Tesis Tidak Dipublikasikan). Universitas Pasundan.

Setyawati, I., Ardiyani, K., \& Sutrisno, C. R. (2015). Faktor-faktor yang Mempengaruhi Niat untuk Melakukan Whistleblowing Internal. Jurnal Ekonomi Dan Bisnis, 17(2), 22-33.

Tjandrawinata, C. L. (2013). Pengaruh Profesionalisme Auditor terhadap Pemahaman Tingkat Materialitas Dalam Pemeirksaan Laporan Keuangan Pada Kantor Akuntan Publik di Surabaya. Calyptra: Jurnal Ilmiah Mahasiswa Universitas Surabaya, 2(1), 1-20.

Widaningsih, M., \& Hakim, D. N. (2015). Pengaruh Profesionalisme Auditor Internal terhadap Pencegahan Pendeteksian Kecurangan (Fraud). Jurnal Riset Akuntansi Dan Keuangan, 3(1), 586-206.

Wijaya, C. L., \& Adechandra, D. (2020). Pengaruh Profesionalisme dan Independensi terhadap Pencegahan Kecurangan dengan Iklim Etika-Egoisme Sebagai Variabel Moderasi. Jurnal Ilmu Sosial Dan Humaniora, 9(1), 78-89.

Zimbelman, M. F., Albrecht, C. C., Albrecht, W. S., \& Albrecht, C. O. (2014). Akuntansi Forensik (4th ed.). Jakarta: Salemba Empat. 